\title{
RANCANGAN SHELTER/HALTE BRT MEBIDANG (BUS RAPID TRANSIT MEDAN-BINJAI-DELISERDANG) UNTUK MEMPERMUDAH AKSESBILITAS MASYARAKAT KEBUTUHAN KHUSUS DENGAN PENDEKATAN ERGONOMI
}

\author{
${ }^{1}$ Chalis Fajri Hasibuan, ${ }^{2}$ Sutrisno \\ ${ }^{1,2}$ Program Studi Teknik Industri, Universitas Medan Area, Jalan. Kolam No 1 Medan Estate, Sumatera Utara \\ e-mail: chalisfajri@yahoo.co.id
}

\begin{abstract}
Abstrak
Desain shelter yang tersedia saat ini jika dilihat masih jauh dari kemudahan aksesbilitas bagi penyandang cacat sedangkan jumlah penyandang cacat yang terdapat dikota Medan untuk cacat tubuh sebayak 2364 jiwa, Deliserdang 2795 jiwa dan Kota Binjai 280 jiwa banyaknya jumlah penyandang cacat yang terdapat di tiga kota dan kabupaten tersebut mengakibatkan perlunya pelayanan publik berupa kemudahan dalam mengakses fasilitas publik ada di ketiga kabupaten kota tersebut dalam hal ini adalah shelter BRT MEBIDANG. Kemudahan dalam mengakses fasilitas sudah diatur dalam keputusan Menteri Pekerjaan Umum No.468/KPTS/1998 yang telah direvisi melalui peraturan Menteri Pekerjaan Umum No.30/PRT/M/2006 tentang persyaratan teknik fasilitas dan aksesbilitas pada bangunan umum dan lingkungan. Dimensi tubuh yang diukur untuk mendapatkan shelter yang sesuai dimensi tubuh yaitu D Diameter Genggaman, Tinggi Siku Duduk, Lebar Bahu, Tinggi Siku Posisi Tegak, Tinggi Badan Tegak, Panjang Telapak Kaki, Panjang Lengan Bawah, Tinggi Polipteal. Hasil perhitungan kecukupan, keseragaman dan kenormalan diperoleh, data yang diperoleh sudah memnuhi kecukupan data, keseragaman data dan kenormalan data. Hasil pengukuran shelter aktual antara lain Tinggi tangga 0.47 m, Panjang $5.06 \mathrm{~m}$, Lebar 2,02 m, Tinggi awalan $0.47 \mathrm{~m}$, Tinggi tempat naik ke Bus 1,11 m, Hasil pengukuran dimensi tubuh yang dikonversi menjadi data dalam perancangan shelter dengan data yang diperoleh Diameter Genggaman Halte : 3.406 cm, Tinggi Pegangan Tingkat 1 Jalur Masuk Halte : 17,99, Tinggi Pegangan Tingkat 2 Jalur Masuk Halte : 90,07 cm, Lebar Ramp : 104 cm, Lebar Tangga Masuk : 65 cm, Lebar Pintu Masuk : 169 cm, Tinggi Pintu Masuk : 229.32 cm, Tinggi Anak Tangga : 20 cm, Lebar Anak Tangga : 20.94 cm, Tinggi Tempat Duduk : $37.5 \mathrm{~cm}$
\end{abstract}

Kata kunci : BRT MEBIDANG. SHELTER, Difable, Ergonomi, Aksesbilitas, Anthropometri

\section{PENDAHULUAN}

Meningkatnya jumlah angkutan umum di kota Medan menimbulkan persoalan transportasi perkotaan. Persoalan tersebut Menurut Tamin (2000), salah satunya adalah kemacetan di daerah perkotaan yang diakibatkan meningkatnya kecenderungan para pemakai jasa transportasi untuk menggunakan kendaraan pribadi dibandingkan dengan kendaraan umum. Perjalanan penumpang di MEBIDANG (Medan-Binjai-Deliserdang) saat ini mencapai lebih dari 600.000 orang per hari. Total tersebut, didominasi oleh pengguna sepeda motor 56,6\%, mobil pribadi 19,3\%, dan angkutan umum 20,6\% (Dishub, 2015), untuk mengurangi penggunaan kendaraan pribadi Bus MEBIDANG memiliki fasilitas yang cukup nyaman dan harga yang murah sehingga banyak masyarakat yang ingin menggunakan angkutan tersebut.

Penumpang yang ingin menggunakan alat transportasi tersebut dapat menggunakan shelter yang disediakan oleh pemerintah provinsi Sumatera Utara untuk memudahkan penumpang untuk menunggu BRT MEBIDANG. Desain shelter yang tersedia saat ini jika dilihat dari studi pendahuluan masih jauh dari kemudahan aksesbilitas. Aksesibilitas masih menjadi persoalan utama yang dihadapi penyandang cacat di ruang publik. Meski Indonesia sudah memiliki seperangkat aturan hukum yang melindungi kaum penyandang cacat, peraturan pemerintah yang mengatur aksesbilitas untuk shelter terdapat pada PERMENDISHUB No 27 Tahun 2015 tentang Standar Pelayanan Minimal Angkutan Massal Berbasis Jalan dimana menyatakan "Fasilitas akses menuju halte yang memberikan kemudahan bagi pengguna jasa yang menggunakan kursi roda, penyandang cacat, manusia usia lanjut, dan wanita hamil", dan keputusan Menteri Pekerjaan Umum No.468/KPTS/1998 yang telah direvisi melalui peraturan Menteri Pekerjaan Umum No.30/PRT/M/2006 tentang persyaratan teknik fasilitas dan 
aksesbilitas pada bangunan umum dan lingkungan. Kenyataannya belum banyak ruang publik yang menyediakan fasilitas, baik fisik maupun non fisik untuk memudahkan aktivitas mereka. Berdasarkan bangunan shelter yang telah didirikan oleh Pemerintah Sumatera Utara yang bekerja sama dengan pemeritah Kota dan Kabupaten belum mengakomodasi aksesbilitas untuk orang dengan berkebutuhan khusus sehingga antara shalter dan BRT tidak memiliki kesamaan fasilitas untuk penyandang cacat, oleh sebab itu maka dalam penelitian ini akan dilakukan perancangan ulang shelter BRT MEBIDANG yang dapat diakses oleh penyandang cacat/berkebutuhan khusus dan penumpang umum sehingga adanya kesamaan perlakuan dalam penggunaan ruang publik dengan pendekatan ilmu ergonomi. Untuk melakukan perancangan shelter yang sesuai dengan aksesbilitas masyarakat disabilitas maka diperlukan pengukuran awal shelter dan pengukuran awal dimensi tubuh dan melakukan pengolahn data terhadap dimensi tubuh

\section{METODE PENELITIAN}

\section{A. Tempat dan Waktu Penelitian}

Penelitian dilakukan pada shelter/halte eksisting BRT MEBIDANG di kabupaten Deliserdang, Kota Medan dan Kota Binjai, waktu penelitian dilaksanakan 17 Juli sampai dengan 26 Agustus 2017. Objek yang diteliti pada penelitian ini adalah shelter/halte MEBIDANG, yang terdapat di kota Medan, Kota Binjai dan Kabupaten Deliserdang.

\section{B. Tahap Identifikasi Masalah}

Tahap ini diawali dengan melakukan studi lapangan untuk mengetahui kondisi shelter bus saat ini. Melakukan perekaman penggunaan shelter oleh masyarakat sehari-hari, perekaman dengan menggunakan kamera digital dan mengambil photo shelter yang ada di MEBIDANG, dan berbagai design dari shelter MEBIDANG yang ada.

\section{Tahap Pengumpulan Data}

Data yang digunakan pada perancangan shelter BRT MEBIDANG meliputi: data layout shelter, dimensi kursi roda, data anthropometri orang normal dan penyandang cacat, dengan menggunakan Human body martin ( model YM-1) sedangkan ukuran aktual dari shelter menggunakan Meteran Buterfly.

\section{Tahap Pengolahan Data}

Tahapan ini meliputi perhitungan persentile dari data anthropometri yang telah dikumpulkan. Persentil data anthropometri ini digunakan untuk merancang pintu masuk dan pintu keluar shelter bus, dan desain ramp. Uji keseragaman data, uji kecukupan data, uji chi-square.

\section{Uji Keseragaman Data}

Uji keseragaman data perlu untuk pengendalian proses bagian data yang ditolak atau tidak seragam (out of control) karena tidak memenuhi batas yang telah ditetapkan.

Peta kontrol adalah suatu alat yang tepat digunakan dalam menguji keseragaman data yang diperoleh dari hasil pengamatan rata-rata. Batas kontrol atas (BKA) serta bata kontrol bawah (BKB) dicari dengan formulasi sebagai berikut:

$$
B K A=\bar{X}+2 \sigma \quad B K B=\bar{X}-2 \sigma
$$

\section{Uji kecukupan data}

Uji kecukupan data, dengan tingkat kepercayaan 95\% dan tingkat ketelitian 5\% dilakukan dengan menggunakan rumus sebagai berikut: 


$$
N^{\prime}=\left[\frac{\frac{k}{s} \sqrt{N\left(\sum X_{i}^{2}\right)-\left(\sum X_{i}\right)^{2}}}{\sum X_{i}}\right]^{2}
$$

Apabila $\mathrm{N}^{\prime}<\mathrm{N}$ maka data pengukuran yang dilakukan sudah mencukupi dan tidak perlu melakukan pengukuran lagi. Apabila jumlah data tidak mencukupi, maka dilakukan pengambilan data lagi.

\section{Uji Kenormalan Data dengan Chi-Square}

Uji kesesuaian antara frekuensi hasil pengamatan dengan frekuensi yang diharapkan, yang tidak memerlukan anggapan tertentu tentang bentuk distribusi populasi dari mana sampel diambil, dapat menggunakan uji chi-square

\section{E. Blok Diagram Prosedur Penelitian}

Dalam tahapan pengolahan data anthropometri beberapa hal yang dilakukan. Hal ini dapat dilihat pada Gambar 1.

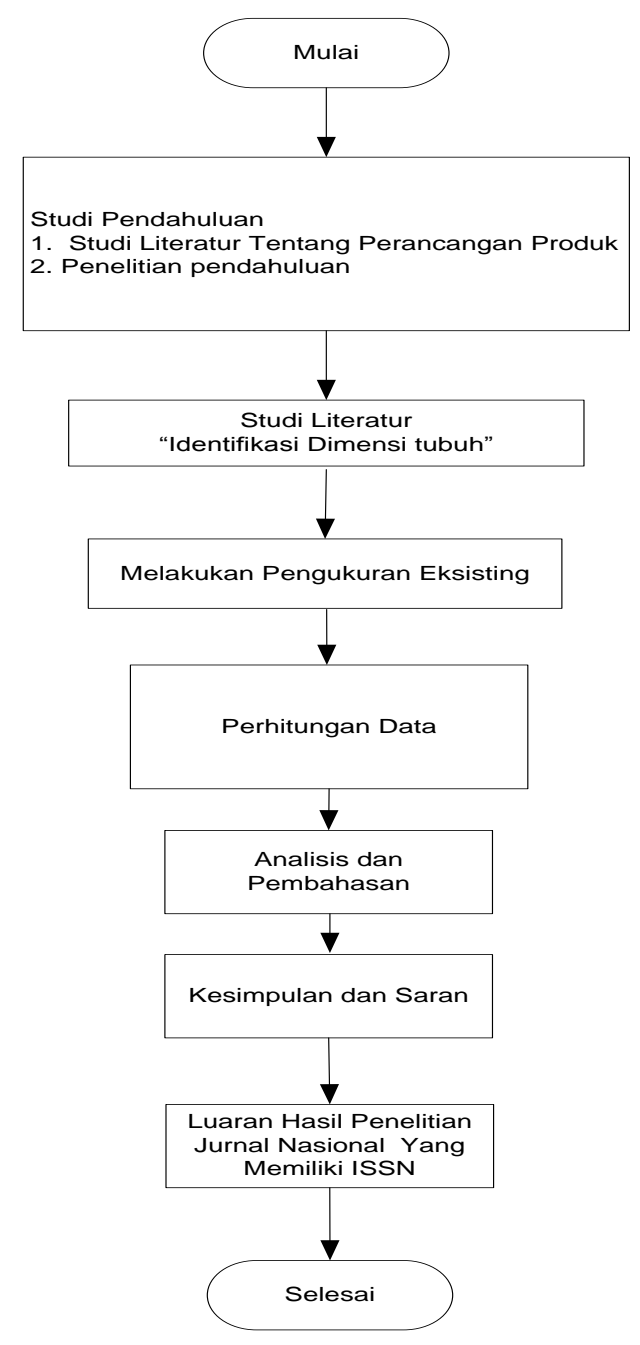

Gambar 1. Prosedur Penelitian 


\section{HASIL DAN PEMBAHASAN}

\section{A. Hasil}

Pengukuran Dimensi Tubuh

Untuk memperoleh dimensi tubuh yang akan digunakan sebagai acuan dalam perancangan shelter diperlukan pengukuran dimensi tubuh sebagai pendekatan human centered design dalam ergonomic dan juga sebagai dasar dalam perancangan fasilitas shelter, dimensi yang digunakan yaitu
DG : Diameter Genggaman
TSD : Tinggi Siku Duduk
LB : Lebar Bahu
TSB : Tinggi Siku Posisi Tegak
TBT : Tinggi Badan Tegak
PTK : Panjang Telapak Kaki
PLB : Panjang Lengan Bawah
TPo : Tinggi Polipteal.

Data dimensi tubuh yang telah ada selanjutnya akan diolah dengan melakukan pengujian keseragamaan data, kecukupan dan normalitas data dengan tahapan sebagai berikut:

\section{Uji Keseragaman Data}

Uji keseragaman data digunakan untuk mengetahui apakah data-data yang diperoleh telah berada dalam keadaan terkendali atau belum. Suatu data yang berada dalam batas kendali yang telah ditetapkan yaitu BKA (Batas Kendali Atas) dan BKB (Batas Kendali Bawah) dapat dikatakan berada dalam keadaan terkendali, sebaliknya jika data berada di luar BKA dan BKB, maka data tersebut berada dalam keadaan tidak terkendali. Suatu data yang berada dalam keadaan tidak terkendali harus dibuang untuk kemudian dilakukan uji keseragaman kembali sehingga tidak tidak ada lagi data yang berada di luar BKA dan BKB. Pada penelitian ini peneliti menggunakan tingkat kepercayaan 95\% dan tingkat ketelitian $5 \%$. Persamaan yang digunakan untuk menguji keseragaman data adalah:

$$
\begin{gathered}
B K A=\bar{X}+2 \sigma \quad B K B=\bar{X}-2 \sigma \\
\overline{\mathrm{X}}=\frac{X_{1}+X_{2}+\ldots .+X_{n}}{n}=\frac{\sum X_{n}}{n}
\end{gathered}
$$

Dimana :

$\mathrm{N}=$ Banyaknya Pengamatan

$\Sigma \mathrm{X}_{\mathrm{n}}=$ Jumlah pengamatan ke $\mathrm{n}$ dari $\mathrm{i}=1$ hingga $\mathrm{j}=34$

$\overline{\mathrm{x}}=$ Nilai rata-rata

\begin{tabular}{|c|c|c|c|c|c|c|c|c|}
\hline SubGroup & & & $\mathbf{n}$ & & & & Jumlah & Rataan \\
\hline I & 5.4 & 4.24 & 4.21 & 4.2 & 4.4 & 3.94 & 26.39 & 4.3983333 \\
\hline II & 4.6 & 3.86 & 4.05 & 3.7 & 4.12 & 4.1 & 24.43 & 4.0716667 \\
\hline II & 3.5 & 4.1 & 4.2 & 3.9 & 3.65 & 4.3 & 23.65 & 3.9416667 \\
\hline IV & 4.2 & 5.18 & 4.01 & 3.4 & 3.2 & 4.2 & 24.19 & 4.0316667 \\
\hline $\mathbf{V}$ & 4.3 & 4.97 & 3.54 & 5.4 & 4.96 & 4.2 & 27.37 & 4.5616667 \\
\hline VI & 4.44 & 4.09 & 4.02 & 4.4 & 4.1 & 4 & 25.05 & 4.175 \\
\hline VII & 4.36 & 4.73 & 3.5 & 4.4 & 4.6 & 4.1 & 25.69 & 4.2816667 \\
\hline & TOTAL & & & & & & 176.77 & 29.461667 \\
\hline
\end{tabular}

Tabel 1. Pembagian Sub Group

Sumber: Pengolahan Data 
Tabel 2. Derajat Kepercayaan

\begin{tabular}{ccccc}
\hline \multicolumn{5}{c}{ Confident Limit $95 / 5$} \\
\hline Subgroup & BKA & Xi Rata & BKB & X- Bar \\
\hline 1 & 5.192 & 4.398333 & 3.226 & 4.21 \\
2 & 5.192 & 4.071667 & 3.226 & 4.21 \\
3 & 5.192 & 3.941667 & 3.226 & 4.21 \\
4 & 5.192 & 4.031667 & 3.226 & 4.21 \\
5 & 5.192 & 4.561667 & 3.226 & 4.21 \\
6 & 5.192 & 4.175 & 3.226 & 4.21 \\
7 & 5.192 & 4.281667 & 3.226 & 4.21 \\
\hline
\end{tabular}

Sumber: Pengolahan Data

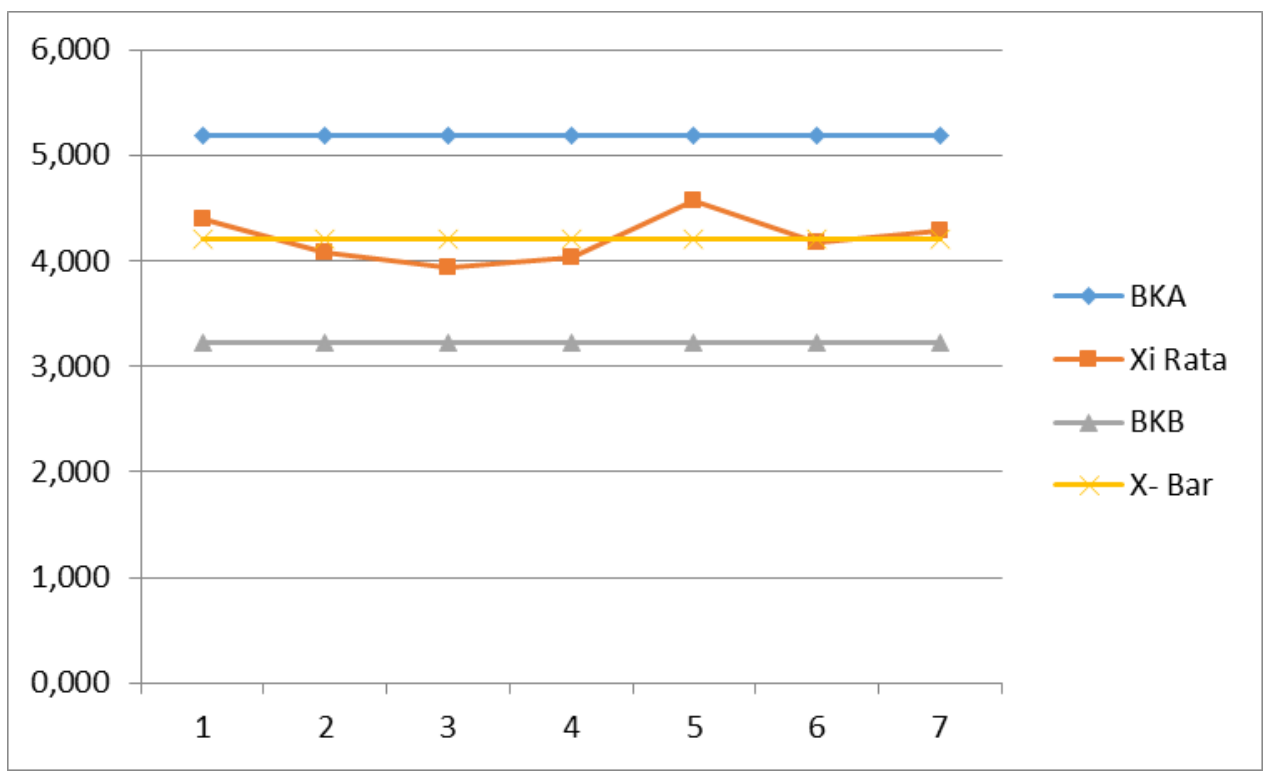

Gambar 2. Uji Keseragaman Data Diameter Genggaman

Tabel 3. Penilaian Keseragaman Data

\begin{tabular}{lcccccccl}
\hline No & $\begin{array}{c}\text { Dimensi } \\
\text { Tubuh }\end{array}$ & $\overline{\mathrm{X}}$ & $\boldsymbol{\sigma}$ & $\boldsymbol{X}_{\text {maks }}$ & $\boldsymbol{X}_{\boldsymbol{m i n}}$ & BKA & BKB & Keterangan \\
\hline 1 & DG & 4.21 & 0.49 & 5.4 & 3.2 & 5.192 & 3.226 & Seragam \\
2 & TSD & 24.22 & 3.80 & 36 & 15 & 31.814 & 16.633 & Seragam \\
3 & LB & 39.22 & 5.27 & 50 & 24.5 & 49.752 & 28.681 & Seragam \\
4 & TSB & 104.08 & 8.54 & 162 & 92.2 & 129.157 & 78.996 & Seragam \\
5 & TBT & 163.21 & 9.69 & 191.1 & 146.8 & 182.582 & 143.837 & Seragam \\
6 & PTK & 24.00 & 1.87 & 30 & 20.5 & 27.742 & 20.248 & Seragam \\
7 & PLB & 26.47 & 5.22 & 55.5 & 22 & 36.919 & 16.024 & Seragam \\
8 & TPo & 43.71 & 3.36 & 57 & 37.5 & 50.436 & 36.992 & Seragam \\
\hline
\end{tabular}

Sumber: Pengolahan Data 


\section{Uji Kecukupan Data}

Uji kecukupan data dengan tingkat ketelitian 5\% dan tingkat kepercayaan 95\% digunakan persamaan :

Keterangan:

$$
N^{\prime}=\left[\frac{40 \sqrt{N\left(\sum_{i=1}^{n} X_{i}^{2}\right)}-\left(\sum_{i=1}^{n} X_{i}\right)^{2}}{\sum_{i=1}^{n} X_{i}}\right]^{2}
$$

$N^{\prime}$ = Jumlah pengamatan yang seharusnya dilakukan (dari hasil perhitungan)

$\mathrm{N}=$ Pengamatan pendahuluan

Jika $\mathrm{N}^{\mathrm{I}}<\mathrm{N}$, maka data pengamatan cukup

Jika $\mathrm{N}^{\mathrm{I}}>\mathrm{N}$, maka data pengamatan kurang dan perlu tambahan data.

$$
N^{\prime}=\left[\frac{40 \sqrt{N \Sigma \mathrm{X}^{2}-(\Sigma \mathrm{X})^{2}}}{\Sigma \mathrm{X}}\right]^{2}=21.29 \quad \mathrm{~N}^{\prime}<\mathrm{N} \quad \begin{gathered}
\text { Maka, Data } \\
\text { Cukup }
\end{gathered}
$$

Hasil pengolahan data yang dilakukan didapat $N^{\prime}<\mathrm{N}(4,29<34)$, maka dapat disimpulkan data yang diperoleh sudah cukup. Uji kecukupan data pada dimensi antropometri lainnya dapat dilihat pada Tabel 4.

Tabel 4. Rekapitulasi Uji Kecukupan Data

\begin{tabular}{lclll}
\hline No & Dimensi & N & N' & Keterngan \\
\hline 1 & DG & 34 & 21.299692 & Cukup \\
2 & TSD & 34 & 38.339552 & Cukup \\
3 & LB & 34 & 28.181995 & Cukup \\
4 & TSB & 34 & 22.675893 & Cukup \\
5 & TBT & 34 & 5.5015288 & Cukup \\
6 & PTK & 34 & 9.5222338 & Cukup \\
7 & PLB & 34 & 15.205575 & Cukup \\
8 & TPo & 34 & 9.2326883 & Cukup \\
\multicolumn{5}{l}{ Sumber: Pengolahan Data }
\end{tabular}

\section{Uji Kenormalan Data dengan Chi-Square}

Penelitian ini pengujian kenormalan datanya dilakukan dengan metode Chi-Square menggunakan software SPSS 16.0 for windows. Metode Chi-Square digunakan karena data antropometri yang digunakan adalah data parametrik yang dapat diketahui nilai parameter/statistik data (rata-rata, standar deviasi, dan sebagainya), merupakan data kontiniu (hasil pengukuran), dan ukuran sampel memenuhi (34 sampel) sehingga metode Chi-Square dapat digunakan untuk melakukan uji kenormalan data. Hasil seluruh pengujian dinyatakan normal karena chi kuadrat (X2) hitung < chi kuadrat (X2) tabel. Pengujian kenormalan data dapat dilihat pada Lampiran dan hasilnya dapat dilihat pada Tabel 5. 
Tabel 5. Hasil Rekapitulasi Uji Chi-Square

\begin{tabular}{ccccc}
\hline No & Dimensi Tubuh & $\begin{array}{c}\text { Chi-Kuadrat } \\
\text { Hitung }\end{array}$ & $\begin{array}{c}\text { Chi-Kuadrat } \\
\text { Tabel }\end{array}$ & Keterangan \\
\hline 1 & DG & 18.762 & 36.41503 & Normal \\
2 & TSD & 14.952 & 31.41043 & Normal \\
3 & LB & 3.238 & 30.14353 & Normal \\
4 & TSB & 3.810 & 33.92444 & Normal \\
5 & TBT & 6.000 & 37.65248 & Normal \\
6 & PTK & 29.143 & 36.41503 & Normal \\
7 & PLB & 24.000 & 30.14353 & Normal \\
8 & TPo & 6.714 & 36.41503 & Normal \\
\hline \multicolumn{2}{l}{ Sumber: Pengolahan Data } & & &
\end{tabular}

Desain Aktual Shelter BRT

Desain aktual dari shelter merupakan desain yang diperoleh dari pengukuran lapangan

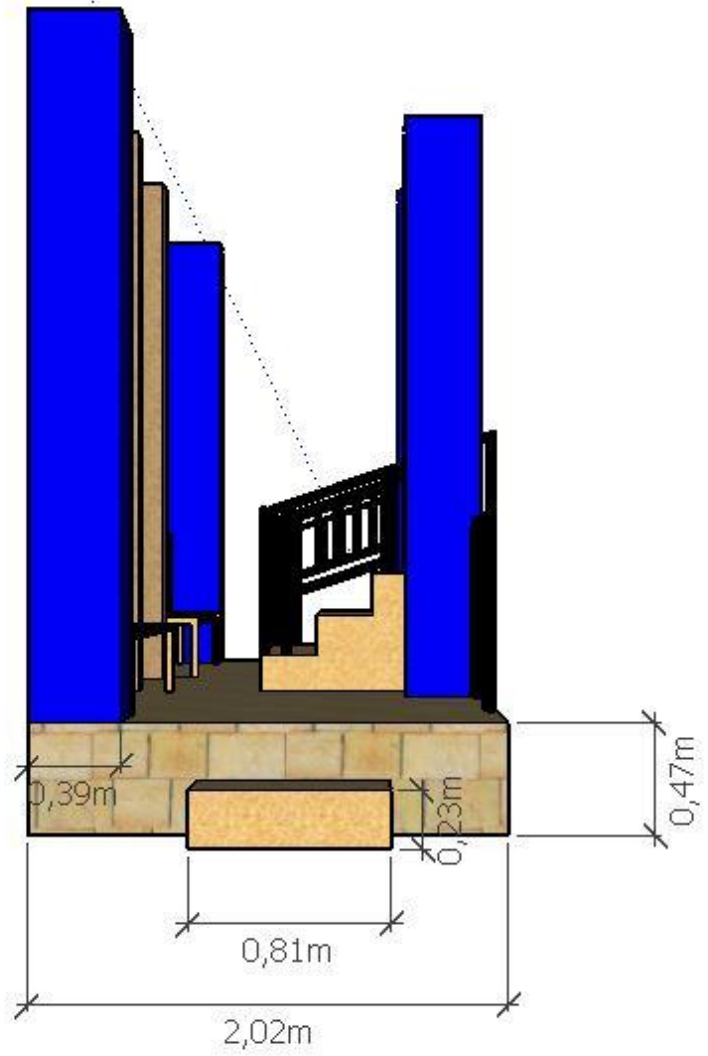

Gambar 3. Tampak Samping Shelter Aktual 


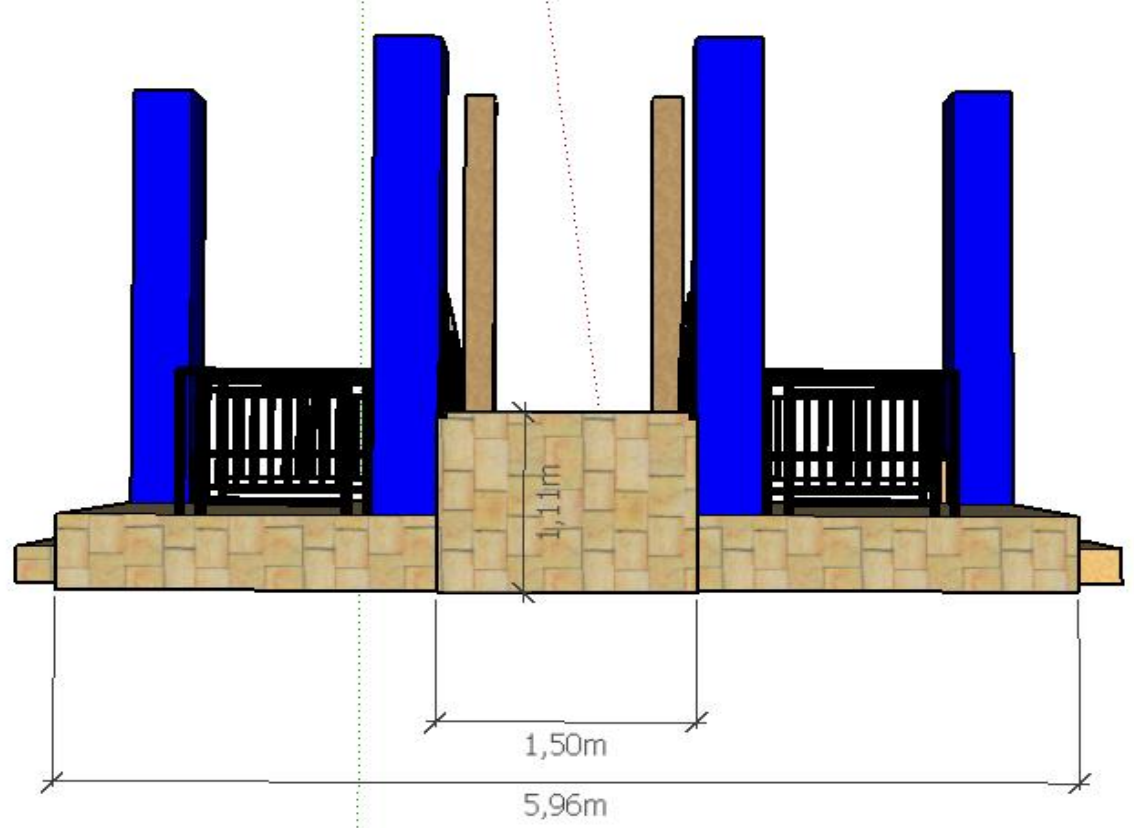

Gambar 4. Tampak Depan Shelter Aktual

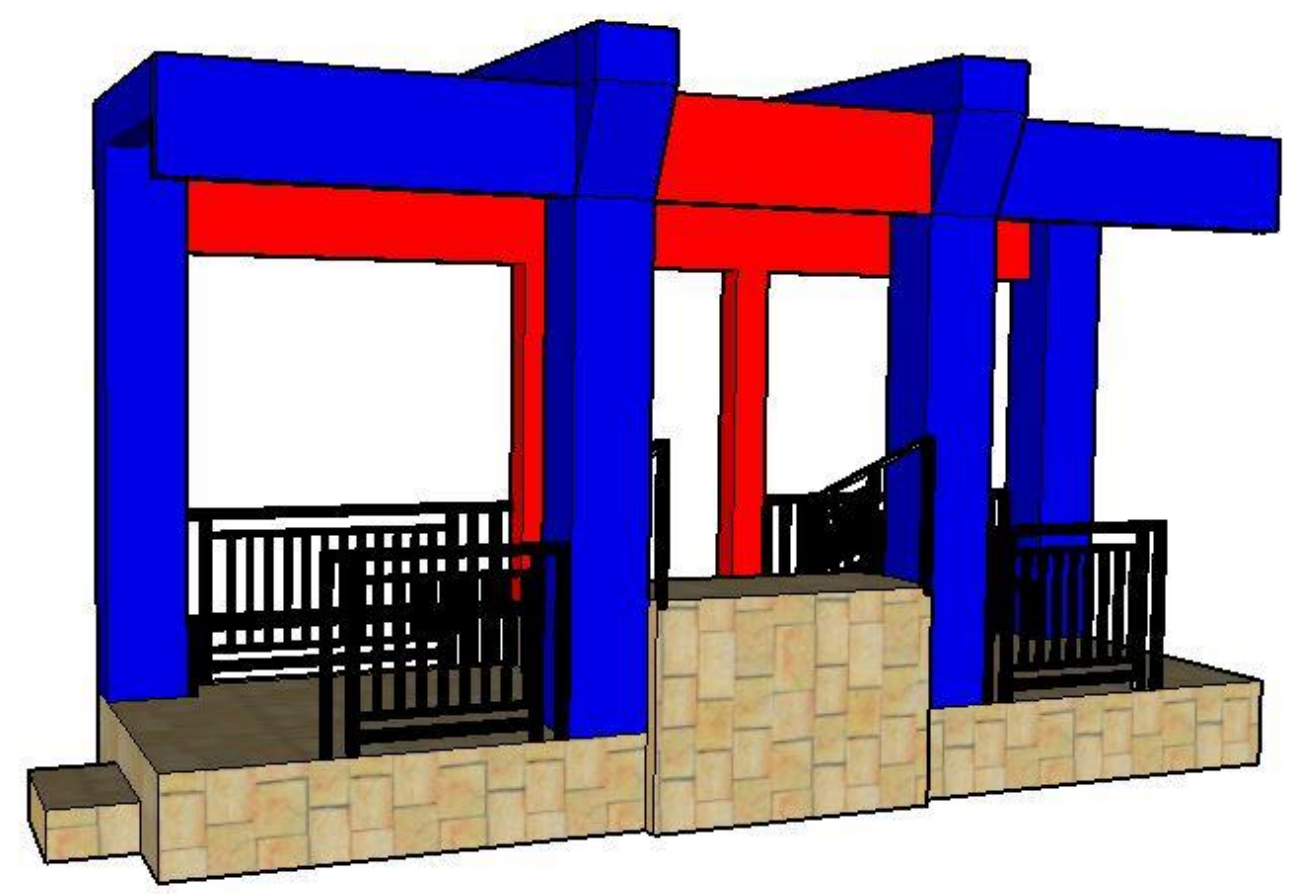

Gambar 5. Tampang 3D Shelter Aktual

\section{Antropometri Untuk Perancangan}

Sebelum menentukan prinsip perancangan, terlebih dahulu mendefenisikan populasi kemudian pemilihan sampel. Pada penelitian ini, yang menjadi populasi adalah pengguna hal bus rapid transit MEBIDANG. Berdasarkan populasi dan sampel yang diperoleh, untuk menentukan dimensi rancangan fasilitas kerja ini menggunakan prinsip penggunaan data antropometri yang ekstrim dan rata-rata tergantung pada dimensinya sehingga seluruh pengguna hal bus rapid transit MEBIDANG mampu menggunakan rancangan fasilitas kerja tersebut dengan nyaman. Berikut hasil perhitungan untuk ukuran rancangan fasilitas kerja berdasarkan hasil pengolahan antropometri. 
1. Diameter Genggaman Halte

Dimensi : Diameter Genggaman

Persentil : 5

Perhitungan : - 1.645(SD) $X$

$$
=4.21-1,64(0.49)=3.406 \mathrm{~cm}
$$

2. Tinggi Pegangan Tingkat 1 Jalur Masuk Halte

Dimensi : Tinggi Siku Duduk

Persentil : 5

Perhitungan : - 1.645(SD) $X$

$$
=24,22-1,64(3,80)=17,99 \mathrm{~cm}
$$

3. Tinggi Pegangan Tingkat 2 Jalur Masuk Halte

Dimensi : Tinggi Siku Posisi Tegak

Persentil : 5

Perhitungan : - 1.645(SD) $X$

4. Lebar Ramp

$$
=104,08-1,64(8,54)=90,07 \mathrm{~cm}
$$

Dimensi : Lebar Bahu + Selisih Lebar Kursi Roda

Ekstrem + Selisih Lebar Kursi Roda +allowance 30\%

Perhitungan : $50+30+24=104 \mathrm{~cm}$

5. Lebar Tangga Masuk

Dimensi : Lebar Bahu

Ekstrem + allowance 30\%

Perhitungan : $50+15=65 \mathrm{~cm}$

6. Lebar Pintu Masuk

Dimensi : Lebar Bahu untuk Ramp dan Tangga

Perhitungan : $104+65=169 \mathrm{~cm}$

7. Tinggi Pintu Masuk

Dimensi : Tinggi Badan Tegak

Ekstrem + allowance

Perhitungan : $191,1+20 \%=229.32 \mathrm{~cm}$

8. Tinggi Anak Tangga

Berdasarkan hasil penelitian bahwa bahwa tinggi anak tangga $20 \mathrm{~cm}$

9. Lebar Anak Tangga

Dimensi : Panjang Telapak Kaki

Perhitungan : - $1.645(\mathrm{SD}) X$

$$
=24,00-1,64(1,87)=20.94 \mathrm{~cm}
$$

10. Tinggi Tempat Duduk

Perhitungan dengan menggunakan nilai ekstrem terkecil

Maka $\mathrm{TPo}=37,5 \mathrm{~cm}$

\section{Desain Shelter Aktual}

Setelah diperoleh hasil dari dimensi tubuh selanjutnya dirancang shelter yang sesuai dengan hasil pengukuran. 


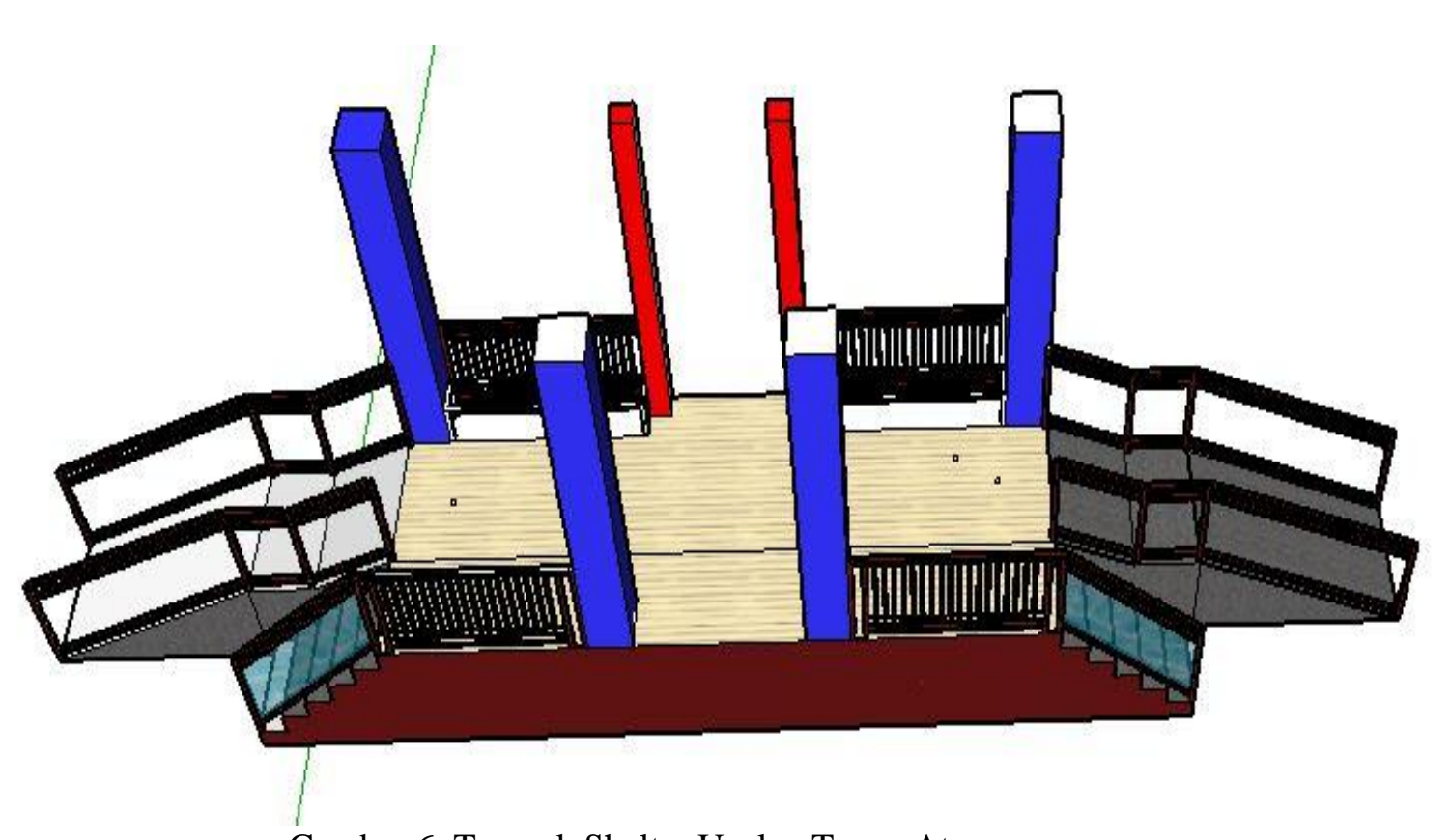

Gambar 6. Tampak Shelter Usulan Tanpa Atap

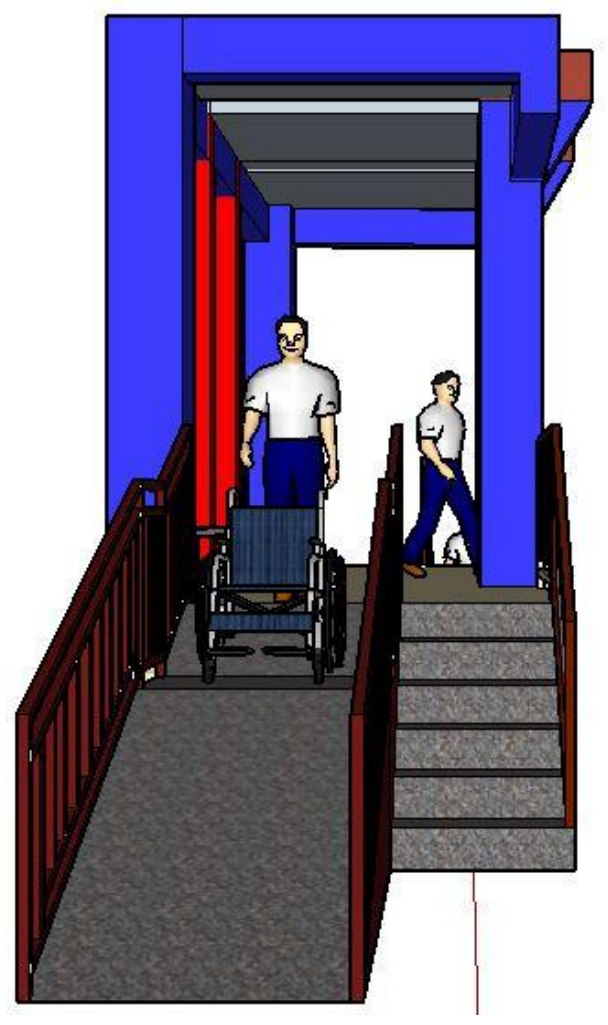

Gambar 7. Tampak Samping Shelter Usulan 


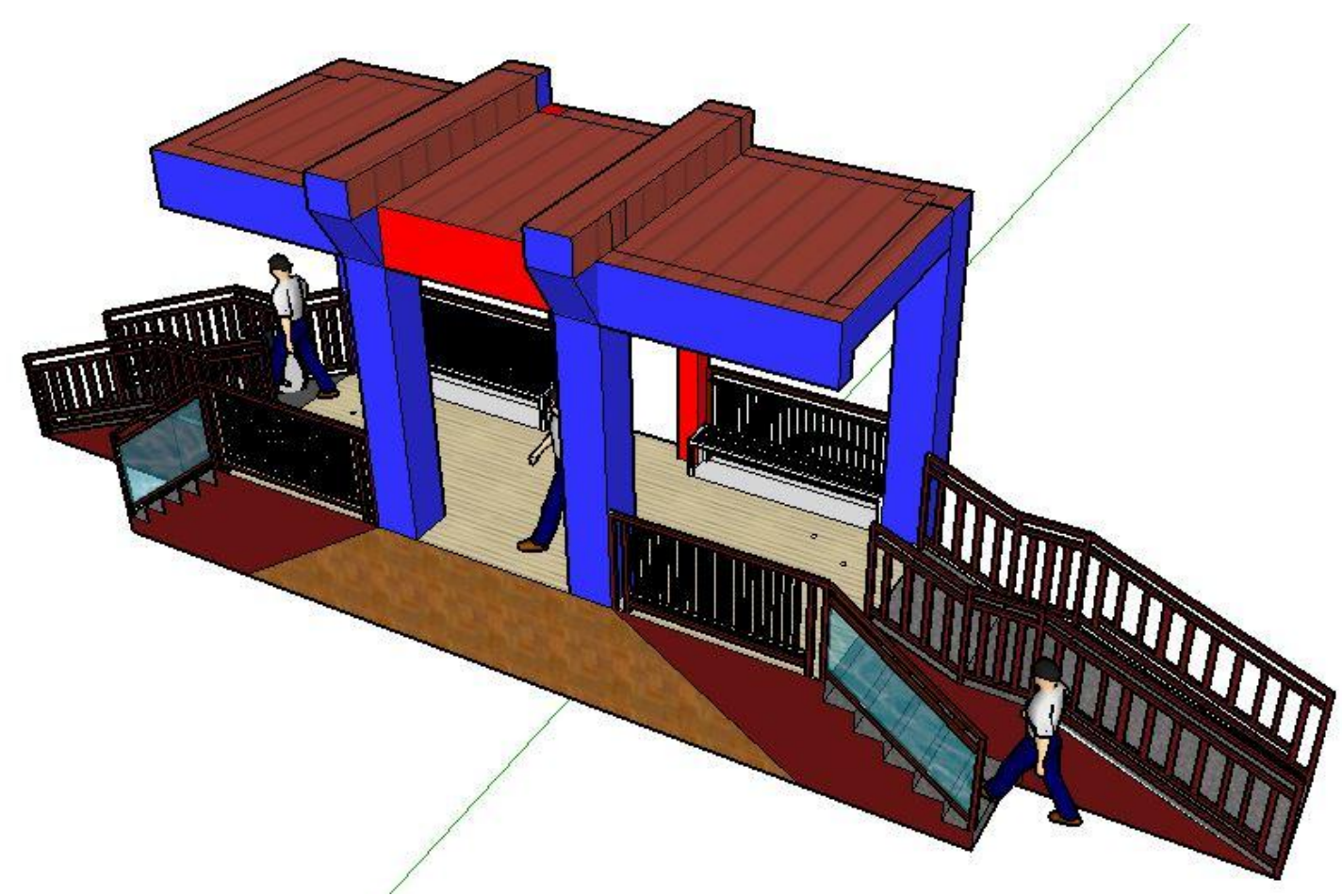

\section{B. Analisis}

Gambar 8. Tampak 3D Shelter Usulan

Shelter bus Trans Jogja merupakan fasilitas umum dimana semua lapisan masyarakat dapat memanfaatkannya termasuk para penyandang cacat. Perancangan shelter ini dibuat guna membantu para penyandang cacat agar dapat mengakses fasilitas dari bus Trans Jogja. Berdasarkan hasil pengumpulan data serta pengamatan di lapaangan, diketahui bahwa dimensi dari shelter bus Trans Jogja tidak memenuhi standar Persyaratan Teknis Aksesibilitas Pada Bangunan Umum dan Lingkungan dengan ukuran awal Tinggi tangga $0.47 \mathrm{~m}$, Panjang $5.06 \mathrm{~m}$, Lebar 2,02 m, Tinggi awalan $0.47 \mathrm{~m}$, Tinggi tempat naik ke Bus $1,11 \mathrm{~m}$, untuk mendapatkan rangan yang sesuai maka di dilakukan perancangan dengan menggunakan dimensi tubuh untuk memperoleh hasil yang sesuai dengan human centered desaign. Hasil pengukuran dimensi tubuh yang dikonversi menjadi data dalam perancangan shelter dengan data yang diperoleh Diameter Genggaman Halte : $3.406 \mathrm{~cm}$, Tinggi Pegangan Tingkat 1 Jalur Masuk Halte : 17,99, Tinggi Pegangan Tingkat 2 Jalur Masuk Halte : 90,07 cm, Lebar Ramp : 104 cm, Lebar Tangga Masuk : 65 cm, Lebar Pintu Masuk : $169 \mathrm{~cm}$, Tinggi Pintu Masuk : $229.32 \mathrm{~cm}$, Tinggi Anak Tangga : $20 \mathrm{~cm}$, Lebar Anak Tangga : 20.94 $\mathrm{cm}$, Tinggi Tempat Duduk : $37.5 \mathrm{~cm}$

\section{SIMPULAN}

Dari hasil penelitian dapat ditarik kesimpulan sebagai berikut:

1. Hasil perhitungan shelter aktual antara lain
a. Tinggi tangga $0.47 \mathrm{~m}$
b. Panjang $5.06 \mathrm{~m}$
c. Lebar $2,02 \mathrm{~m}$
d. Tinggi awalan $0.47 \mathrm{~m}$
e. Tinggi tempat naik ke Bus $1,11 \mathrm{~m}$

2. Dimensi tubuh yang dubutuhkan untuk desain shelter antara lain
a. DG
: Diameter Genggaman
b. TSD
: Tinggi Siku Duduk
c. LB : Lebar Bahu
d. TSB : Tinggi Siku Posisi Tegak 

e. TBT : Tinggi Badan Tegak
f. PTK : Panjang Telapak Kaki
g. PLB : Panjang Lengan Bawah
h. TPo : Tinggi Polipteal.

3. Berdasarkan hasil uji kecukupan, uji kenormalan, dan uji keseragaman data dari data dimensi tubuh dihasilkan bahwa data yang diambil cukup, data dalam batas normal dan data yang diuji juga dalam keadaan seragam sebagai syarat penggunaan data ke tahap selanjutnya.

4. Hasil Perhitungan Shelter Usulan Antara lain
a. Diameter Genggaman Halte : $3.406 \mathrm{~cm}$
b. Tinggi Pegangan Tingkat 1 Jalur Masuk Halte : 17,99
c. Tinggi Pegangan Tingkat 2 Jalur Masuk Halte : 90,07 cm
d. Lebar Ramp : $104 \mathrm{~cm}$
e. Lebar Tangga Masuk : $65 \mathrm{~cm}$
f. Lebar Pintu Masuk : $169 \mathrm{~cm}$
g. Tinggi Pintu Masuk : $229.32 \mathrm{~cm}$
h. Tinggi Anak Tangga : $20 \mathrm{~cm}$
i. Lebar Anak Tangga : $20.94 \mathrm{~cm}$
j. Tinggi Tempat Duduk : $37.5 \mathrm{~cm}$

Adapun yang menjadi saran dalam penelitian ini adalah

1. Pengambilan data dimensi tubuh menggunakan peralatan yang lebih canggih lagi sehingga data yang diperoleh lebih tepat

2. Perancangan shelter harus mengedepankan human centered desaign bukan hanya sekedar menyelesaikan pembangunan

\section{DAFTAR PUSTAKA}

Lubis, Herry, Julaihi Wahid, 2005, Persepsi Pelaku Perjalanan Terhadap Pelayanan Angkutan Umum Di Kota Medan, Jurnal Arsitektur “ATRIUM" vol. 02 no. 03

Nevala-Puranen, Nina; Markku Seuri; Ahti Simola; and Jyrki Elo. 1999. Physically Disabled at Work: Need for Ergonomic Interventions. Journal of Occupational Rehabilitation. Vol. 9, No. 4

Pratiwi, Intan. 2012. Aksesibilitas Masih Setengah-Setengah. Majalah Pledoi. JuliAgustus 2012, hal. 4-10.

Suhardi, B, Laksono, P.W. 2013, Redesain Shelter Bus Trans Jogja Dengan Pendekatan Anthropometri Dan Aksesibilitas, Jurnal Ilmiah Teknik Industri, Vol. 12, No. 2

Suhardi, Bambang; dan Sudadi. 2013. Perancangan Tempat Tidur Periksa Untuk Orang Lanjut Usia. Prosiding Seminar Nasional Terpadu Keilmuan Teknik Industri. Malang: Program Studi Teknik Industri Universitas Brawijaya.

Suhardi, Bambang; dan Fitri Yulianti Suryono. 2013. Perancangan Kursi Bus Untuk Wanita Hamil Berdasarkan Aspek Ergonomi. Prosiding Seminar Nasional Terpadu Keilmuan Teknik Industri. Malang: Program Studi Teknik Industri Universitas Brawijaya. 